\title{
Corporate Cash Holdings and Agency Conflicts: Evidence from Moroccan Developing Market
}

\author{
Boubker Mouline*, Hicham Sadok \\ Faculty of Juridical, Economic and Social Sciences, Mohammed V University in Rabat, Souissi, Morocco
}

Received November 17, 2020; Revised December 8, 2020; Accepted January 20, 2021

\section{Cite This Paper in the following Citation Styles}

(a): [1] Boubker Mouline, Hicham Sadok, "Corporate Cash Holdings and Agency Conflicts: Evidence from Moroccan Developing Market," Universal Journal of Accounting and Finance, Vol. 9, No. 1, pp. 24 - 32, 2021. DOI: 10.13189/ujaf.2021.090103.

(b): Boubker Mouline, Hicham Sadok (2021). Corporate Cash Holdings and Agency Conflicts: Evidence from Moroccan Developing Market. Universal Journal of Accounting and Finance, 9(1), 24 - 32. DOI: 10.13189/ujaf.2021.090103.

Copyright@2021 by authors, all rights reserved. Authors agree that this article remains permanently open access under the terms of the Creative Commons Attribution License 4.0 International License

\begin{abstract}
The topic of corporate cash holdings has received relatively little attention from academic researchers. However, this decision has always been at the center of interest of any company seeking to improve its performance. This article aims to examine the relationship between agency costs related to managerial discretion and cash holdings by Moroccan companies. In order to do this, we will mobilize both agency theory and free cash flow theory. To date, and to our knowledge, no research has been conducted on the cash flow of Moroccan companies in the light of agency theory. This study contributes to cash holdings research in Morocco by exploring the reasons for holding cash through a sample of Moroccan non-financial companies that are listed on the Casablanca Stock Exchange for a period of 12 years (from 2007 to 2018). This research uses econometric models based on a positivist approach with a hypothetical-deductive method. Our results show that there is a strong positive relationship between cash holdings and cash flow. It also turns out that the liquidity of these companies is significantly negatively affected by the debt leverage and the growth opportunities of the company.
\end{abstract}

Keywords Cash Holdings, Morocco, Agency Theory, Free Cash Flow Theory, Firm-specific Variables

\section{Introduction}

The interest in the problem of corporate cash holdings is continuously growing as figures illustrate the sustainable trend of increasing corporate cash reserves around the world over time. For example, the liquidity ratio of listed European companies increased on average from $8 \%$ to $17 \%$ of total assets between 1980 and $2015^{1}$. However, classical financial theory teaches us that companies should aim for zero cash. As cash management tools become increasingly sophisticated, one might have expected an evolution towards this theoretical optimum, meaning a decrease in the average levels of cash held. In reality, the opposite has happened: cash levels are high and have been growing constantly over the past 35 years. Numerous international studies confirm this observation, for instance, the average cash ratio was $23.2 \%$ for US companies in 2016, compared with 10.5\% in 1980 (Bates, Kahle \& Stulz, 2009), 12.33\% on average in Australia over the period 1990-2015 (La Cava \& Windsor, 2016), and 12\% in India over the period 2005-2015 (Arora, 2019). So, what are the reasons why companies hold cash? According to neoclassical financial theory, the question of holding cash is not relevant. In fact, in the friction-free world of Modigliani and Miller (1958), the investment decision is separated from the financing decision. The company can evaluate its investment opportunities without worrying about how they will be financed because of its ability to raise funds on the financial market or to

\footnotetext{
${ }^{1}$ Moody's: Cash holdings US corporates recede in H1 2018 on back of tax reform” Moody's Investors Service, November 27, 2018 , https://www.moodys.com/research/Moodys-Cash-holdings-US-corporate s-recede-in-H1-2018-on--PR_392219 
sell assets on the market at no cost. However, in the real world, companies have an incentive to hold a certain level of liquidity. By questioning the restrictive assumptions of neoclassical finance, recent developments in contemporary finance have revealed the motivations and consequences of holding cash. These sketches of insight are understood in terms of trade-off theory (Opler et al., 1999), hierarchical order theory (Myers and Majluf, 1984), and agency theory (Jensen, 1986).

According to trade-off theory, the optimal level of liquidity is the result of a compromise between the benefits and costs of holding cash. The creation of a safety cushion, which avoids the costs of external financing or liquidation of the firm's assets, would be the main benefit that the firm can derive from holding cash and would also allow the firm to exercise its future investment options. However, holding cash has a cost to the firm. There are two types of cash costs. First, the rate of return on liquid assets is limited and is often lower than the cost of the firm's resources. The very presence of cash therefore reduces the profitability of the firm. Second, the assessment of the costs and benefits of liquidity may differ between shareholders and management. In particular, managers may wish to hold a high level of cash in order to serve their own interests and increase their autonomy (Opler et al., 1999). This cost resulting from agency problems between shareholders and management and the low return on cash relative to other assets of the firm are the main costs of holding cash. This theory has been confirmed by several recent empirical works (Elyasiani \& Zhang, 2015; Yogesh Maheshwari \& Vigneswara, 2017; Asimakopoulos, Asimakopoulos \& Fernandes 2019).

A different view of treasury is based on the explanation of the pecking order theory, which states that there is no optimal level of debt and that, consequently, the firm does not have an optimal financial structure (Myers \& Majluf, 1984). The firm would first use the company's liquid funds to finance an acquisition or a new project, then issue risk-free debt, and later, risk debt or convertible bonds before opting to issue shares. The company's objective is to avoid situations where it is forced to abandon profitable investment projects or to issue undervalued shares. This is largely due to the existence of information asymmetry in the financial market between investors and company managers. In fact, managers have information that investors do not have and act in the interest of former shareholders. Potential investors are faced with the risk of overvaluation of the company's shares. Faced with this risk, potential investors may demand that the shares be issued at a lower value than the stock market price. This fear makes recourse to the capital market costly because of the risk of adverse selection on the company's assets. In contrast to trade-off theory, few empirical studies have been able to consolidate the pecking order theory (Sher 2014; Graham \& Leavy 2018).

The explanation based on the agency theory puts forward the impact of the managerial discretionary behavior on the level of cash holdings by the firm. This theory explains that this discretionary behavior occurs when part or all of the capital is transferred to an independent shareholder, thus resulting in a manager-shareholder relationship with the risk of a conflict of interest. This divergence of interests is due to the reduction of the manager's share in the capital, which reduces their share of dividends, reduces their motivation to maintain net income at a high level, and pushes them to appropriate other firm resources in the form of indirect benefits (Jensen \& Meckling 1976). Numerous international studies confirm this theory with their empirical results (J. Harford et al. 2008; Al-Najjar \& Belghitar, 2011; Uyar \& Kuzey, 2014)

The characteristics of the economic environment where Moroccan firms operate, namely weak creditor and shareholder protection, ineffective law enforcement, and high shareholder concentration, make Morocco an ideal setting to study this issue and offer the best territory for the establishment of several types of agency problems. This is why we are working on this article in the framework of agency and free cash flow theories. In order to provide an input to the cash holding behavior of Moroccan firms, we will analyze the liquidity of 38 Moroccan companies listed on the Casablanca Stock Exchange over a period of 12 years (from 2007 to 2018).

This article will be organized as follows. In the first point, we briefly review the literature focusing on agency theory and free cash flow theories. This review highlights the determinants of cash holdings and identifies the important variables that influence the firm's decision to hold cash. Next, we examine methodology and sampling. We then present the results and their analysis, and finally summarize the main results in our conclusion.

\section{Literature Review}

The agency theory was pioneered by Berle and Means in 1932, who showed how separation of ownership and control impacts organizations. They did this by analyzing the development of several corporations in the United States of America in the 1930s, and then publishing their findings in a famous book entitled The Modern Corporation and Private Property in 1932. They were not the first to have stressed the impact of the separation of ownership and control in business corporations. Long before that, Adam Smith (1776) raised this issue and announced that management in corporations is entrusted to the directors, while shareholders admitted that they do not interfere in the management of their company by simply receiving dividends. Faced with this situation, Adam Smith (1776) raised the risk of indifference, excessive spending, and lack of vigilance on the part of non-owner managers in the administration of shareholders' interests and wealth. In their book, Berle and 
Means (1932) found that organizations no longer met the requirements of the classic model of the organization where owners-controlled management. They state that management control in modern companies is exercised with limited intervention by the owners.

This led them to acknowledge the emergence of a separation between the functions of ownership and control. The authors announced the appearance of a new corporate system dominated by a diversified and dispersed shareholder base that sided with individual ownership rights. They expressed their fear of the economy being dominated by a minority of large firms where several shareholders holding a small percentage of the capital would be deprived of their management rights, and then risk being misappropriated by non-owner managers. In this regard, Berle and Means have distinguished five main types of control: control through almost complete ownership of the capital, majority control, control through a legal mechanism for issuing non-voting shares, minority control, and control by management. Management control is exercised when the shareholder base is diversified to the extent that no group of shareholders can have sufficient voting rights to control the company. In companies, where the ownership structure is widely dispersed, the election of board members is entrusted to power funds that hold the voting mandates. The proxy holders can appoint themselves as members of the board of directors. Whoever has the power to make up the board has control, because the members of the board will certainly act according to the board's interests. Otherwise, the members will be replaced. Berle and Means (1932) point out that in modern companies with diversified shareholdings, owners do not assume any role in the management of their capital contributions because they have abandoned their tasks of controlling the company by delegating them to management. In this way, they share the profits distributed by the company without being able to exercise control over investments and the continuity of their business. The separation of ownership from control in widely held companies and their sharing between shareholders and non-owner managers serves as a basis for promoting the agency theory. These assumptions are regarded by Jensen and Meckling (1976) as the basic elements of agency theory, which in turn defines the agency relationship between the owners of the firm who present themselves as shareholders on one hand, and the persons who have been entrusted with the management of the firm and who present themselves as managers on the other. An agency relationship is established when the actions of one person affect both his or her utility and that of another person as a result of an explicit or implicit contractual relationship. The person undertaking the actions is the "agent" hired to perform one or more tasks on behalf of the "principal" whose utility is affected by the actions of their agent. The relationship between firm owners and non-owner managers is a perfect illustration of this, given the divergent interests between them (Jensen \& Meckling, 1976).

The firm's holding of the remaining cash left after the financing of all the projects with a positive net present value called "Free Cash-Flow" represents a significant part of the divergence of interest between manager and owner and, therefore, of agency costs (Jensen, 1986). In fact, the latter creates conflicts of interest between the managers of a company and its shareholders. Since they are not the sole owners of the companies they manage, the managers could act against the interests of the shareholders in return for their own. In such situations, managers seek to increase the amount of liquid assets themselves for several reasons: Kruger (2015) shows, for example, that a high level of liquidity increases losses through expenditures on projects with negative NPVs. In fact, cash holding allows managers to finance projects with a negative NPV or low rate of return that the capital markets would not accept to finance, or simply use the liquidity for their interests by increasing the benefits in nature and thus derive more private benefits. The presence of cash encourages managers to diversify into projects that are not necessarily successful and that belong to sectors of activity in which they are familiar with in order to extend their discretionary power (Charreaux, 1997). Thus, one of the easiest ways for executives to achieve their goal is to accumulate cash rather than distributing it to shareholders in the form of dividends or share buybacks. In this way, executives avoid the use of capital markets and their controls (Dittmar \& Marth-Smith, 2007; Coulier, 2008). This divergence of interest between the principal and the agent leads to reflections and maneuvers to encourage the agent to behave in a way that maximizes not only his utility, but also that of the principal (Jensen \& Meckling, 1976).

To investigate the relationship between agency costs related to opportunistic management behavior and cash holdings by firms, previous research has used explanatory variables to test managerial discipline.

\section{Determinants of Cash Holdings}

The literature review suggests several explanatory variables for firms' behaviour when holding cash. The determinants selected from the theoretical and empirical literature are justified in their expected impact on the level of cash holdings. The main determinants of cash holdings can be summarized below.

\section{Size}

Larger companies usually have dispersed structures, and where ownership is widely dispersed, shareholders have little power over management, which prevents them from forcing managers to distribute the cash they have accumulated in the form of dividends or share buybacks. Consequently, due to managerial discretion, the level of 
cash will be high (Drobetz \& Grüninger, 2007). Likewise, being seen as an anti-takeover device, size reduces the disciplinary role of takeover bids by limiting their number and contributing to the entrenchment of managers. From what has been advanced, we can make the following assumption: H.1 "Firm size has a positive impact on the level of liquid asset holdings".

\section{Debt}

Managers of low-indebtedness firms have little control over capital markets and can, therefore, hold high levels of cash without being disciplined by them (Opler et al., 1999). Jensen (1986) suggests using debt to align the deviant behavior of managers. In fact, debt is seen as a disciplinary mechanism that forces managers to dispose of cash that they would not have distributed to shareholders in the form of dividends. Otherwise, the company would face the risk of receivership or liquidation. The relationship between cash and debt is, therefore, negative. The research of Yogesh and Vigneswara (2017) confirms this negative relationship by demonstrating that firms whose main source of financing is debt are less confronted with agency costs. From what has been advanced, we can make the following assumption: H.2 "Corporate indebtedness has a negative impact on the level of liquid asset holdings".

\section{Dividends}

The payment of dividends indirectly avoids the problems of opportunistic behavior of managers (Easterbrook, 1984; Jensen, 1986). This is because the distribution of profits will force company managers to turn to bank loans to finance new investments, and thus submit to the pressure and constraint of the financial market. So we can make the following assumption: H.3 "Dividend distribution has a negative impact on the level of holdings of liquid assets".

\section{Cash flow}

According to agency theory (Jensen, 1986), the higher the firm's cash flow, the greater the agency costs between management and shareholders will be. The manager seeking his interest will see this as an opportunity to maximize the liquid assets at their disposal rather than using them optimally. The relationship between the cash and cash flow would then be positive. Therefore, we can advance the following hypothesis: H.4 "Cash flow has a positive impact on the level of liquid asset holdings".

\section{Growth opportunities}

According to agency theory, firms with limited growth opportunities are more exposed to discretionary management risk, since in the absence of sufficient growth and investment opportunities, managers are more likely to accumulate the most liquidity to benefit from their discretionary power (Opler et al., 1999), and to then reinvest them in unprofitable projects related to their career and experience, fostering their entrenchment (Ferreira \& Vilela, 2004; Afza \& Adnan, 2007). Several empirical studies document a significantly negative relationship between growth opportunities and cash holdings (Afza \& Adnan, 2007; Baklouti \& Bouri, 2015; Yogesh \& Vigneswara, 2017). Growth opportunities are measured by Tobin's Q ratio calculated by dividing the market value of equity (Market Capitalization) plus the value of net financial debt over the net book value of the firm's assets (Book Value). Since netbook assets do not consider the presence of growth opportunities, Tobin's Q will be high for companies with growth opportunities. Therefore, we can assert the following hypothesis: H.5 "Growth opportunities are negatively correlated with cash holdings".

\section{Financial distress}

As several authors explain, firms in financial distress suffer from lower agency costs because of the disciplinary role of financial pressure on managers who find themselves forced to make optimal use of the available funds at their disposal, fearing the risk of bankruptcy of the firm (Kim et al., 1998; Drobetz \& Grüninger, 2007). The relationship between financial distress and liquidity would then be negative. Thus, hypothesis H.6 can be established as follows: "Financial distress has a negative impact on the level of ownership of liquid assets".

\section{Larger shareholder}

The control of managers is essential in reducing agency conflicts between shareholders and managers. However, for a minority shareholder, the cost of supervision is greater than the benefit it can derive from it, so it is not in their interest to effectively control the managers. On the other hand, the benefits that a major shareholder derives from the supervision of managers exceed the costs it incurs, and therefore it is in their interest to effectively supervise them. Concentration of ownership is therefore associated with more effective control of managers (Shleiferr and Vishny, 1986). From these findings, we can make the following hypothesis H.7: "The percentage of capital held by the majority shareholder has a negative impact on cash holding”.

\section{The board size}

The literature suggests that the number of directors on the board is supposed to shape the quality of the board's supervisory activities. The ability of a board to better control managerial behavior depends primarily on the ease of communication and cooperation in the meeting room, which in turn depends on the number of directors. Lipton 
and Lorsch (1992) argue that large boards of directors are less effective and easier for a CEO to dominate, as many directors tend to be "polite and courteous" rather than critical of management decisions. While large boards probably offer greater potential for knowledge and skills, their organizational deficiencies, increased potential for conflict, and the risk of the existence of stowaways appear to be much greater (Yermack 1996). This allows us to make the following hypothesis H.8: The size of the board of directors has a negative impact on cash holdings.

The following Table 1 summarizes all the determinant:

Table 1. Variable definition summary.

\begin{tabular}{|l|l|}
\hline Variables & Measure \\
\hline Cash Holding (Cash) & Cash and Cash equivalent/Net total assets \\
\hline Company size (Size) & Natural Logarithm of total assets \\
\hline Debt Ratio (Debt) & $\begin{array}{l}\text { Total of long and short-term debt/Total } \\
\text { assets }\end{array}$ \\
\hline Dividend (Divid) & Total distributed dividends/Total assets \\
\hline Cash flow (Cf) & $\begin{array}{l}\text { Earning before interest + depreciation } \\
\text { /Total assets }\end{array}$ \\
\hline $\begin{array}{l}\text { Growth } \\
\text { opportunities } \\
\text { (Tobin's Q) }\end{array}$ & $\begin{array}{l}\text { Equity Market Value + Liabilities Market } \\
\text { Value/ Equity Book Value Liabilities Book } \\
\text { Value }\end{array}$ \\
\hline Financial distress & $\begin{array}{l}\text { The risk of financial distress is measured } \\
\text { by the inverse of the Z- score bankruptcy } \\
\text { prediction model developed by Altman } \\
\text { (1968) }\end{array}$ \\
\hline $\begin{array}{l}\text { Largest shareholder } \\
\text { (1st Share) }\end{array}$ & $\begin{array}{l}\text { \% of the capital held by the largest } \\
\text { shareholder }\end{array}$ \\
\hline $\begin{array}{l}\text { Board size } \\
\text { (BD-Size) }\end{array}$ & Number of directors \\
\hline
\end{tabular}

\section{Methodology}

We conducted an empirical econometric study using a positivist approach based on a hypothetico-deductive method according to the methodology advocated by Gill and Johnson, (2010). We used data extracted from the financial statements of 38 companies listed on the Casablanca Stock Exchange during the period 2007-2018. These companies were selected for two main reasons. Firstly, listed companies have access to both financing markets, namely the banking and capital markets, which gives them the capacity to have a comprehensive financing policy and strategy. The second reason lies in the characteristics of accounting and financial data of listed Moroccan firms, which can be considered accessible, exhaustive, and reliable, unlike unlisted companies. We use panel regression analysis in our study for the advantages it offers compared to time series data, notably a larger sample size, less collinearity, consideration of section heterogeneity, and better efficiency.
As for the choice of sampling, the target population includes companies listed on the Moroccan market between 2007 and 2018, the data of which are available on the Casablanca Stock Exchange website. However, for the purpose of the study, companies in the financial sector ${ }^{2}$ are excluded given the specificity of their liquidity needs. Firms for which data are missing or are not listed continuously over the entire period of the study are also eliminated ${ }^{3}$.

Analysis of the data for all the firms in the sample reveals the presence of outliers. The existence of these outliers may alter the regression results by masking existing relationships or by artificially revealing them. These points are removed.

Table 2. Study sample

\begin{tabular}{|l|c|c|}
\hline & Companies & Observations \\
\hline Starting sample & 75 & 900 \\
\hline$\bullet \quad$ Financial companies & 11 & 132 \\
\hline$\bullet \quad$ Insurance & 5 & 60 \\
\hline$\bullet \quad \begin{array}{l}\text { Stock market information } \\
\text { missing }\end{array}$ & 21 & 252 \\
\hline Companies studied & 38 & 456 \\
\hline
\end{tabular}

The purpose of econometrics in this study is to estimate the coefficient $\beta$ by using panel data regression analysis.

Cash i, $t=\alpha+\beta 1$ Size i,t $+\beta 2$ Cash flow i,t $+\beta 3$ Debt i,t $+\beta 4$ Dividend $i, t+\beta 5$ Tobin's $q$ i, $t+\beta 6$ Financial distress $+\beta 71^{\text {st }}$ Share $i, t+\beta 8$ CEO-Dual i,t $+\varepsilon \mathrm{i}, \mathrm{t}$

\section{Results and Discussion}

The data for our variables were collected from the reports and financial statements published by 38 listed companies on the Casablanca stock exchange. In what follows, We will first present descriptive statistics of the explanatory variables, as well as the univariate analyses of the data, and on the other hand the presentation and interpretation of the results of the regression tests.

\section{Descriptive statistics}

Table 3 below presents descriptive statistics for the dependent variable "Cash holding" (Cash) that characterizes our sample of Moroccan firms. We find that the average level of liquidity is $10.35 \%$ with a minimum of $0.0 \%$ and a maximum of $73.6 \%$, although the median level of cash holdings is $4.11 \%$, indicating that some firms hold relatively large amounts of cash relative to the median value.

\footnotetext{
2 Financial companies are excluded from our sample because their liquidity holdings are linked to requirements other than those examined in pur article.

3 The company must be listed on a market and data must be available for a minimum of ten consecutive years.
} 
Table 3. Descriptive statistics for the dependent variable

\begin{tabular}{|c|c|c|c|c|c|}
\hline Variable & Mean & Median & SD & Minimum & Maximum \\
\hline Cash & $10.35 \%$ & $4.11 \%$ & $13.90 \%$ & $0.00 \%$ & $73.60 \%$ \\
\hline
\end{tabular}

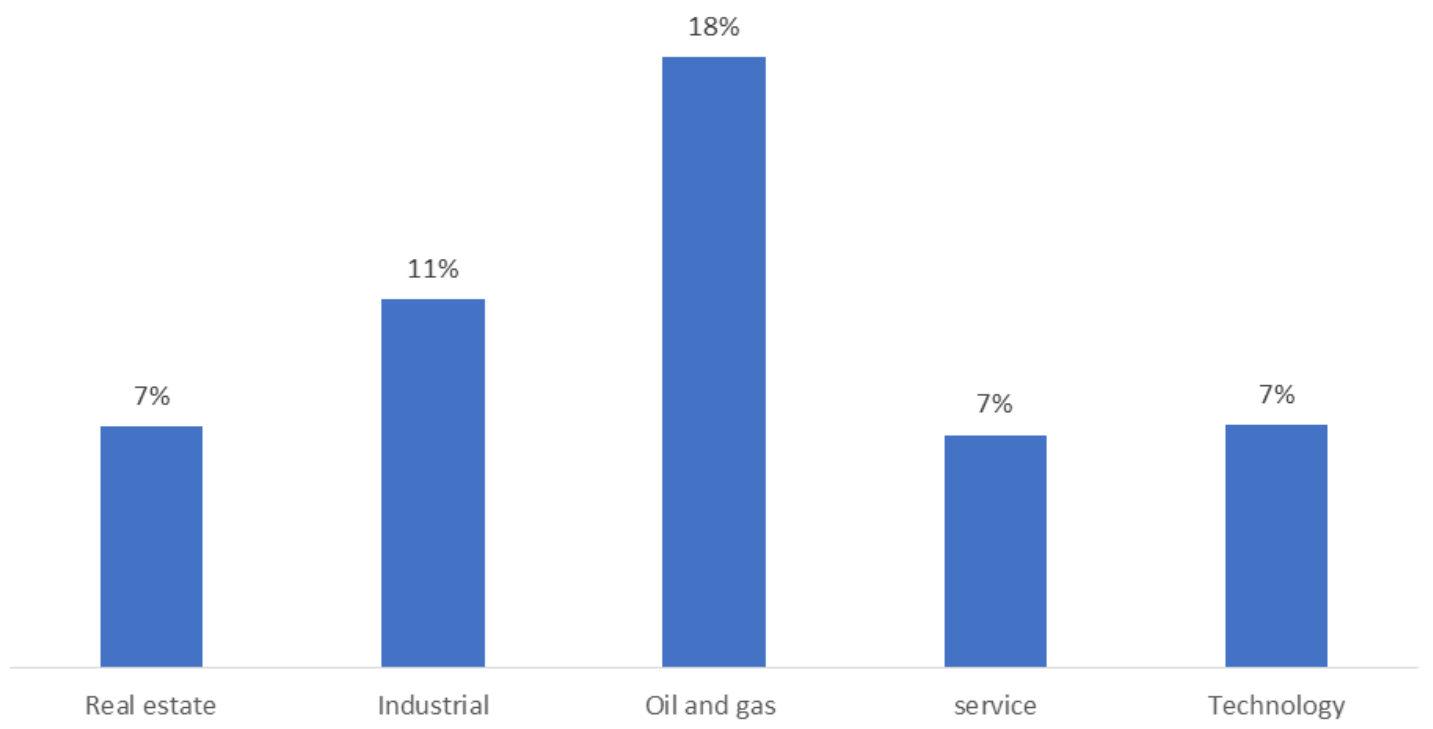

Figure 1. Average level of cash holdings by sector

Figure 1 shows the cash ratio by business segment. It can be noted that it is in the oil and gas mining sector that the average cash level is highest, representing $18 \%$ of net assets, followed by the industrial sector with an average of $11 \%$. Finally, the technology, real estate and service sector have a similar average liquidity holding of around $7 \%$ of net assets for the total sample.

Table 4. Descriptive statistics for the independent variables

\begin{tabular}{|c|c|c|c|c|c|}
\hline Variable & Mean & Median & SD & Minimum & Maximum \\
\hline Size & 8.76 & 8.93 & 0.6 & 7.5 & 10.63 \\
\hline Debt & $35 \%$ & $36 \%$ & $17 \%$ & $0 \%$ & $98 \%$ \\
\hline CF & $16 \%$ & $13 \%$ & $16 \%$ & $-5 \%$ & $144 \%$ \\
\hline DIVID & $6 \%$ & $4 \%$ & $7 \%$ & $0 \%$ & $76 \%$ \\
\hline Tobin's Q & 3.13 & 2.39 & 2.43 & -3.48 & 19.66 \\
\hline $\begin{array}{c}\text { Financial } \\
\text { Distress }\end{array}$ & 0.24 & 0.17 & 1.12 & -10.05 & 9.03 \\
\hline 1st Share & $48 \%$ & $51 \%$ & $22 \%$ & $7.5 \%$ & $97 \%$ \\
\hline BD-Size & 8 & 8 & 3 & 3 & 17.00 \\
\hline
\end{tabular}

Regarding the characteristics of the companies in our total sample over the period 2007-2018, they are summarized in Table 4 . As can be seen, the average size in our total sample is 8.76 with the standard deviation of 0.6 . The mean value for debt is $35 \%$ and its standard deviation is $17 \%$. The average value of cash flow is $16 \%$ and its standard deviation is $16 \%$. On average, companies in our sample pay out about $6 \%$ of their assets in the form of dividends with a standard deviation of $7 \%$. The average value for tobin'q is 3.13 with a standard deviation of 2.43. The mean value of financial distress is 0.24 with a standard deviation of 1.12. The first shareholder has been identified and the variables "1st Share" measure the percentage held by each of them. The first shareholder holds on average $48 \%$ of the capital. The average board size is eight members.

Table 5 below presents the correlation coefficients between the variables in our study. This matrix shows that all the explanatory variables are correlated with the explained variable with a risk of error below $1 \%$ with the exception of the financial distress and the 1st Share variables which have an insignificant correlation coefficient. The strongest positive correlation coefficient shows a correlation between cash and cash flow of 0.55 , while the largest negative correlation coefficient concerns debt and the holding of liquidity to the value of -0.23 . As for the other significant coefficients, it varies between -0.18 and 0.36 . The correlation coefficients between the explained variable cash position and the explanatory variables, cash flow, dividend and board size are significant and positive; whereas the variables size, debt, and Tobin's Q are all negative and significant. Furthermore, no correlation coefficient reaches the threshold of 0.6. We can then conclude that our study is not affected by the risk of multicollinearity. 
Table 5. Correlation matrix

\begin{tabular}{|c|c|c|c|c|c|c|c|c|c|}
\hline Variable & Cash & Debt & Cf & Size & Divid & Tobin's q & Financial Distress & 1st Share & BD-size \\
\hline \multirow[t]{2}{*}{ Cash } & 1.00 & -0.23 & 0.55 & -0.18 & 0.21 & -0.13 & -0.38 & 0.04 & 0.12 \\
\hline & & $* *$ & $* *$ & $* *$ & $* *$ & $* *$ & & & $* *$ \\
\hline \multirow[t]{2}{*}{ Debt } & -0.23 & 1.00 & -0.20 & 0.31 & -0.27 & 0.24 & 0.30 & 0.06 & -0.02 \\
\hline & $* *$ & & $* *$ & $* *$ & $* *$ & $* *$ & $* *$ & & \\
\hline \multirow[t]{2}{*}{$\mathrm{Cf}$} & 0.53 & -0.20 & 1.00 & -0.02 & 0.46 & 0.12 & -0.28 & 0.01 & 0.03 \\
\hline & $* *$ & $* *$ & & & $* *$ & $* *$ & * & & \\
\hline \multirow[t]{2}{*}{ Size } & -0.18 & 0.29 & -0.02 & 1.00 & 0.15 & 0.30 & 0.09 & 0.15 & 0.36 \\
\hline & $* *$ & $* *$ & & & $* *$ & $* *$ & $*$ & $* *$ & $* *$ \\
\hline \multirow[t]{2}{*}{ Divid } & 0.22 & -0.27 & 0.48 & 0.17 & 1.00 & 0.19 & 0.23 & 0.12 & 0.10 \\
\hline & $* *$ & $* *$ & $* *$ & $* *$ & & $* *$ & $* *$ & $* *$ & $* *$ \\
\hline \multirow[t]{2}{*}{ Tobin's Q } & -0.13 & 0.23 & 0.12 & 0.29 & 0.19 & 1.00 & 0.11 & 0.20 & 0.16 \\
\hline & $* *$ & $* *$ & $* *$ & $* *$ & $* *$ & & $*$ & $* *$ & $* *$ \\
\hline \multirow[t]{2}{*}{$\begin{array}{c}\text { Financial } \\
\text { distress }\end{array}$} & -0.05 & 0.10 & -0.04 & 0.14 & 0.05 & 0.20 & 1.00 & 0.07 & -0.06 \\
\hline & & $*$ & & $* *$ & & $* *$ & & & \\
\hline \multirow[t]{2}{*}{ 1st Share } & 0.04 & 0.06 & 0.01 & 0.15 & 0.11 & 0.20 & 0.06 & 1.00 & -0.05 \\
\hline & & & & $* *$ & $* *$ & $* *$ & & & \\
\hline \multirow[t]{2}{*}{ BD-size } & 0.12 & -0.02 & 0.03 & 0.37 & 0.10 & 0.16 & -0.07 & -0.05 & 1.00 \\
\hline & $* *$ & & & $* *$ & $* *$ & $* *$ & & & \\
\hline
\end{tabular}

Table 5 shows the Pearson correlation coefficients between all the explanatory and explanatory variables. We note that there are no correlation problems between the variables that could bias our results.

** The correlation is significant at the 0.01 level (two-tailed)

* The correlation is significant at the 0.05 level

\section{Regression results and interpretation}

Table 6. Regression results

\begin{tabular}{|c|c|c|c|}
\hline Variable & OLS & Fixed Effects & Random Effects \\
\hline \multirow{2}{*}{ Size } & -0.061 & -0.132 & -0.028 \\
\hline & $* * *$ & & \\
\hline \multirow{2}{*}{ Debt } & -0.102 & -0.116 & -0.083 \\
\hline & $* *$ & $* *$ & \\
\hline \multirow{2}{*}{ CF } & 0.12 & 0.049 & 0.091 \\
\hline & $*$ & $*$ & $* *$ \\
\hline \multirow{2}{*}{ Divid } & -0.324 & -0.379 & -0.28 \\
\hline & & & \\
\hline \multirow{2}{*}{ Tobin's q } & -0.006 & -0.007 & -0.002 \\
\hline & $* *$ & $* *$ & $*$ \\
\hline \multirow{2}{*}{$\begin{array}{c}\text { Financial } \\
\text { distress }\end{array}$} & -0.013 & -0.036 & -0.074 \\
\hline & & & \\
\hline 1st Share & -0.024 & -0.101 & -0.021 \\
\hline \multirow[b]{2}{*}{ BD-size } & 0.011 & 0,005 & 0,002 \\
\hline & , $*$, & $*$ & 0,002 \\
\hline \multirow{2}{*}{ Constant } & 0.445 & 0.249 & 0.354 \\
\hline & $* * *$ & & $* *$ \\
\hline Observation & 456 & 456 & 456 \\
\hline $\mathrm{R} 2$ & 0.192 & 0.112 & 0.17 \\
\hline \multirow[t]{2}{*}{ F-Test } & & $8.54(0.18)$ & \\
\hline & & $* *$ & \\
\hline \multirow[t]{2}{*}{ Hausman Test } & & & $2.95(0.00)$ \\
\hline & & & $* * *$ \\
\hline
\end{tabular}

Table 6 presents the results of the following three regression models that we estimated to examine the impact of our variables on liquidity levels for our total sample

Table 6 presents the estimation results using 3 regression methods: random effects, fixed effects and OLS. The explanatory variables in all regression models are: Size, Debt, Cash flow, Working capital requirement, Dividend, Family shareholding, Shareholder concentration.

***The correlation is significant at the 0.01 level.

**The correlation is significant at the 0.05 level.

* The correlation is significant at the 0.1 level.

According to our estimation models, there is a significant relationship between cash holdings and all the explanatory variables with a risk of error between $1 \%$ and $10 \%$, with the exception of the financial distress variable. This implies that this firm-specific characteristic is not relevant in explaining the cash-holding decisions of the firms in our sample. The majority of our significant results are consistent with our hypotheses based on agency theory, and are in line with most of the available empirical results. For example, we show that Moroccan firms hold less cash when their debt levels are high, supporting H2, which explains that debt is a disciplinary mechanism that reduces managers' discretionary latitude and forces them to spend excess cash (Jensen, 1986). Moreover, the positive and significant coefficient of cash flow at the $1 \%$ threshold according to our result validates our H.4 hypothesis. In fact, the cash flow generated by the firm will be accumulated in order to build up cash reserves by managers to increase their discretionary power and become rooted in the firm. Finally, in line with Yogesh and Vigneswara (2017), we find that Moroccan companies 
with significant growth opportunities tend to accumulate less cash, thereby confirming H.5, which explains that the risk of over-investment is greater when companies have available liquidity funds and few investment opportunities, given that managers are more likely to accumulate the most cash to strengthen their discretionary power and increase their rooting within the company. The size of the board is positively related to the company's cash position at the $1 \%$ threshold, which means that the larger the size of the director's board is, the higher the cash position is. In fact, a large board tends to increase agency costs (Yemack 1996). In addition, the lack of harmony between the ideas of board members gives managers room to maneuver and increase their discretionary power. This finding supports hypothesis H.8, that large boards of directors do not provide effective control over management, thereby increasing cash resources.

However, we found some results that clearly contradict our predictions. Our estimation model shows that larger Moroccan firms hold more cash on their balance sheets. This contradicts H1. It is important, however, to note that these two contrasting results to our hypotheses are in line with numerous empirical works based on financial structure theories (Ferreira \& Vilela 2004; Bates et al. 2009; Graham \& Leavy 2018).

\section{Conclusions}

This paper studies the liquidity holding decision by Moroccan firms based on a sample of non-financial firms listed on the Casablanca Stock Exchange during the period 2007-2018 in light of agency theory and free cash flow theory. Our empirical results show that our two explanatory theories play an important role in explaining the behavior of Moroccan firms in terms of cash holdings. In fact, in line with the predictions of the agency and free cash flow theories, our results indicate that the level of indebtedness is negatively related to liquidity. We were also able to show that companies with a high level of cash flow and larger board accumulate significantly higher cash reserves. Finally, we have shown that companies with significant growth opportunities have a lower level of cash holdings than other companies. These results are consistent with the findings of Iskandar and Jia (2014) and Chen et al (2015).

\section{Limitation and implications}

As with any research work, this paper has a number of limitations. The first one is a generic limitation, which all empirical studies suffer from. Indeed, the results obtained in our various studies have been obtained on samples and for specific periods of time. They are thus not universal and can be questioned by other samples.

Concerning the limitations specific to our study, we can conclude that our study could have gained relevance if the variable "cash holdings" used from company balance sheets was available on a monthly or quarterly basis. In fact, cash holdings change constantly during the year and a dynamic analysis would be more appropriate.

The main purpose of this work is to contribute to the preliminary results in this field and to shed additional light on a current topic still very little discussed in Morocco. This research has thus made it possible to broaden the field of knowledge in terms of cash holding decisions in Moroccan companies to the extent that we have made a minor contribution to the contextualization of existing knowledge in this research theme, as well as to the understanding of the behavior of companies and their main trends in terms of cash holdings, including the objectives and motivations of managers.

\section{REFERENCES}

[1] Afza, T.,and Adnan Sh, M. (2007). " Determinants of Corporate Cash Holdings: A Case Study of Pakistan ", Singapore Economic review and University of Manchester, Pp 164-165.

[2] Al-Najjar, B., \& Belghitar, Y. (2011). Corporate cash holdings and dividend payments: evidence from simultaneous analysis. Managerial and Decision Economics, 32(4), 231-241. https://doi.org/10.1002/mde.1529

[3] Arora, R. K. (2019). Corporate Cash Holdings: An Empirical Investigation of Indian Companies. Global Business Review, 20(4), 1088-1106. https://doi.org/10.1177 /0972150919844911

[4] Baklouti, I., \& Bouri, A. (2015). Les déterminants de la détention de trésorerie: La Revue des Sciences de Gestion, 273-274(3), 57-65. https://doi.org/10.3917/rsg.273.0057

[5] Bates, T. W., Kahle, K. M., \& Stulz, R. M. (2009). Why Do U.S. Firms Hold So Much More Cash than They Used To? The Journal of Finance, 64(5), 1985-2021. doi:10.1111/j.1540- 6261.2009. 01492.x

[6] Berle, A. A., \& Means, G. C. (1932). The modern corporation and private property. New York, NY: Macmillan.

[7] Charreaux, G. (1997). Conseil d'administration et pouvoirs dans l'entreprise. Le gouvernement des entreprises, Corporate governance: théories et faits, 142

[8] Chen, Y., Dou, P. Y., Rhee, S. G., Truong, C., \& Veeraraghavan, M. (2015). National culture and corporate cash holdings around the world. Journal of Banking \&amp; Finance, 50, 1-18. doi:10.1016/j.jbankfin.2014.09.018

[9] Dittmar, A., \& Mahrt-Smith, J. (2007). Corporate governance and the value of cash holdings. Journal of Financial Economics, 83(3), 599-634.https://doi.org/10.101 6/j.jfineco.2005.12.006

[10] Drobetz, W., \& Grüninger, M. C. (2007). Corporate cash holdings: Evidence from Switzerland. Financial Markets and Portfolio Management, 21(3), 293-324. https://doi.org/10.1 
007/s11408- 007-0052-8

[11] Easterbrook F.H., (1984). Two Agency-Cost Explanations of Dividends. American Economic Review, Vol. 74, pp. 650-659.

[12] Elyasiani, E., \& Zhang, L. (2015). CEO entrenchment and corporate liquidity management. Journal of Banking \& Finance, vol. 54, Pp 115-128. doi: 10.1016/j.jbankfin.2015. 01.014

[13] Ferreira, M. A., \& Vilela, A. S. (2004). Why Do Firms Hold Cash? Evidence from EMU Countries. European Financial Management, 10(2), 295-319. https://doi.org/10.1111/j.135 4- 7798.2004.00251.x

[14] Gill, J. and P. Johnson, (2010). « Research Methods for Managers », Sage Publications 4th Edition. London.

[15] Graham, J. R., \& Leary, M. T. (2018). The Evolution of Corporate Cash. The Review of Financial Studies, 31(11), 4288-4344. https://doi.org/10.1093/rfs/hhy075

[16] Harford, J., Mansi, S. A., \& Maxwell, W. F. (2008). Corporate governance and firm cash holdings in the US. Journal of Financial Economics, 87(3), 535-555. https://doi.org/10.1016/j.jfineco.2007.04.002

[17] Iskandar-Datta, M. E., \&amp; Jia, Y. (2014). Investor protection and corporate cash holdings around the world: New evidence. Review of Quantitative Finance and Accounting, 43(2), 245- 273. doi:10.1007/s11156-013-0371 $-\mathrm{y}$

[18] Jensen, M. C., \& Meckling, W. H. (1976). Theory of the firm: Managerial behavior, agency costs and ownership structure. Journal of Financial Economics, 3(4), 305-360. https://doi.org/10.1016/0304-405x(76)90026-x

[19] Jensen, M. (1986). Agency cost of free cash-flow, corporate finance and takeovers. the American Economic Review, Vol 76, Pp 323-329.

[20] Kim, C.-S., Mauer, D. C., \& Sherman, A. E. (1998). The Determinants of Corporate Liquidity: Theory and Evidence. The Journal of Financial and Quantitative Analysis, 33(3), 335-358. https://doi.org/10.2307/2331099

[21] Krüger, P. (2015). Corporate goodness and shareholder wealth. Journal of Financial Economics, 115(2), 304-329. https://doi.org/10.1016/j.jfineco.2014.09.008
[22] La Cava, G., \& and Windsor, C. (2016). Why Do Companies Hold Cash?. ReserveBank of Australia Rasearch paper discussion series 2016-03

[23] Lipton, M. and Lorsch, J.W. (1992). A modest proposal for improved corporate governance. Business Lawyer, Vol 48(1), Pp 59-77.

[24] Maheshwari, Y., \& Rao, K. T. V. (2017). Determinants of Corporate Cash Holdings. Global Business Review, 18(2), 416-427. https://doi.org/10.1177/0972150916668610

[25] Modigliani, F., \& Miller, M. H. (1958). The Cost of Capital, Corporation Finance and the Theory of Investment. The American Economic Review, 48, 261-297.

[26] Myers, S. C., \& Majluf, N. S. (1984). Corporate financing and investment decisions when firms have information that investors do not have. Journal of Financial Economics, 13(2), 187-221. https://doi.org/10.1016/0304-405x(84)90023-0

[27] Opler, T. (1999). The determinants and implications of corporate cash holdings. Journal of Financial Economics, 52(1), 3-46. https://doi.org/10.1016/s0304-405x(99)00003-3

[28] Opler, T., Pinkowitz, L., Stulz, R. M., and Williamson, R. (1999). The Determinants and Implications of Corporate Cash Holdings. Journal of Financial Economics, Vol 52, Pp 3-46.

[29] Sher, G. (2014). Cashing in for growth: Corporate Cash Holdings as an Opportunity for Investment in Japan. IMF Working Papers, 14(221), 1.https://doi.org/10.5089/978149 8322171.001

[30] Shleifer, A., \& Vishny, R. (1986). Large shareholders and corporate control. Journal of Political Economy, Vol 94, Pp 461-488.

[31] Smith, A. (1776). An inquiry into the nature and causes of the wealth of nations. Dublin: Printed for Messrs. Whitestone, Chamberlaine, W. Watson, Potts, S. Watson, Hoey

[32] Uyar, A., \& Kuzey, C. (2014). Determinants of corporate cash holdings: Evidence from the emerging market of Turkey. Applied Economics, vol. 46(9). Pp 1035-1048. doi:10.1080/00036846.2013.866203

[33] Yermack, D., (1996). Higher market valuation of companies with a small board of directors. Journal of Financial Economics, Vol 40, Pp 185-212. 